\title{
Synthesis and Biological Activity of Phospholipase C-Resistant Analogues of Phosphatidylinositol 4, 5-bisphosphate
}

\author{
Honglu Zhang ${ }^{1}$, Yong $\mathbf{X u}^{1}{ }^{1}$, Zheng Zhang ${ }^{2}$, Emily R. Liman ${ }^{2}$, and Glenn D Prestwich ${ }^{1,{ }^{*}}$ \\ 1 Department of Medicinal Chemistry, The University of Utah, 419 Wakara Way, Suite 205, Salt Lake City, \\ Utah 84108-1257 USA \\ 2 Department of Biological Sciences and Program in Neuroscience, University of Southern California, 3641 \\ Watt Way, Los Angeles, California 90089-2520 USA
}

\section{Abstract}

The membrane phospholipid phosphatidylinositol 4,5-bisphosphate $\left(\operatorname{Ptd} \operatorname{Ins}(4,5) \mathrm{P}_{2}\right)$ is an important regulator in cell physiology. Hydrolysis of $\operatorname{PtdIns}(4,5) \mathrm{P}_{2}$ by phospholipase $\mathrm{C}$ (PLC) releases two second messengers, Ins $(1,4,5) \mathrm{P}_{3}$ and diacylglycerol. To dissect the effects of PtdIns $(4,5) \mathrm{P}_{2}$ from those resulting from PLC-generated signals, a metabolically-stabilized analogue of PtdIns $(4,5) \mathrm{P}_{2}$ was required. Two analogues were designed in which the scissile $\mathrm{O}-\mathrm{P}$ bond was replaced with a $\mathrm{C}$ $\mathrm{P}$ bond that could not be hydrolyzed by PLC activity. Herein we describe the asymmetric total synthesis of the first metabolically-stabilized, phospholipase C-resistant analogues of PtdIns $(4,5)$ $\mathrm{P}_{2}$. The key transformation was a $\mathrm{Pd}(0)$-catalyzed coupling of an $H$-phosphite with a vinyl bromide to form the desired C-P linkage. The phosphonate analogues of $\operatorname{PtdIns}(4,5) \mathrm{P}_{2}$ were found to be effective in restoring the sensitivity of the TRPM4 channel to $\mathrm{Ca}^{2+}$ activation.

The membrane phospholipid phosphatidylinositol 4,5-bisphosphate $\left(\operatorname{Ptd} \operatorname{Ins}(4,5) \mathrm{P}_{2}\right)$ is an important regulator of cytoskeletal organization during a plethora of cellular functions such as vesicle trafficking, endocytosis, phagocytosis, focal adhesion formation, and cell migration.

${ }^{1} \mathrm{PtdIns}(4,5) \mathrm{P}_{2}$ binds to and affects the function of many actin-binding and actin-remodeling proteins, ${ }^{2-4}$ and is a cofactor in enzyme activation. ${ }^{5}$ In addition, $\operatorname{PtdIns}(4,5) \mathrm{P}_{2}$ regulates the activity of many ion channels and transporters. ${ }^{6,7} \mathrm{Ptd} \operatorname{Ins}(4,5) \mathrm{P}_{2}$ is also the source of three second messengers: Ins $(1,4,5) \mathrm{P}_{3}$, diacylglycerol $(\mathrm{DAG})^{8,9}$ and $\operatorname{PtdIns}(3,4,5) \mathrm{P}_{3} \cdot{ }^{10}$ In many cases, it is the decrease in PtdIns $(4,5) \mathrm{P}_{2}$, resulting from hydrolysis by phospholipase C (PLC) (Scheme 1), and not the increase in $\operatorname{Ins}(1,4,5) \mathrm{P}_{3}$ and DAG, that constitutes the physiologically relevant signal. ${ }^{11,12}$ Hydrolysis of PtdIns $(4,5) \mathrm{P}_{2}$ causes TRP channels to lose some activity. 13-19 Moreover, addition of PtdIns(4,5) $\mathrm{P}_{2}$ restores sensitivity of TRPM4 and TRPM5 to activation by $\mathrm{Ca}^{2+}$ and restores the sensitivity of TRPM8 and TRPV1 to thermal and chemical stimuli. ${ }^{15,16,18,19}$

The availability of a metabolically-stabilized analogue of $\operatorname{Ptd} \operatorname{Ins}(4,5) \mathrm{P}_{2}$, i.e., one that lacks the scissile $\mathrm{P}-\mathrm{O}$ bond and thus could not be hydrolyzed by PLC activity, would have many applications in understanding the role of $\operatorname{Ptd} \operatorname{Ins}(4,5) \mathrm{P}_{2}$ in cell physiology. $\alpha-$ Fluoroalkylphosphonates have emerged as important non-hydrolyzable mimics for phosphoesters in the synthesis of biologically-active "unnatural products". ${ }^{20-23}$ Herein we describe the first asymmetric total synthesis of isosteric and isoelectronic phosphonate analogues $\mathbf{1}-\mathbf{5}$ of PtdIns $(4,5) \mathrm{P}_{2}$ that cannot be hydrolyzed by PLC. The synthesis employs a $\operatorname{Pd}(0)$ coupling not previously exploited in phospholipid or phosphoinositide synthesis. 
Furthermore, we demonstrate that both saturated and unsaturated $\alpha$-fluorophosphonate analogues can substitute for exogenous PtdIns(4,5) $\mathrm{P}_{2}$ in restoring the sensitivity of the TRPM4 channel to $\mathrm{Ca}^{2+}$.

The synthetic sequence to the stabilized analogues $\mathbf{1 - 5}$ of PtdIns $(4,5) \mathrm{P}_{2}$ is illustrated in Scheme 2. A variety of attempts to connect the intermediate $9^{24}$ with a fluoromethylenephosphonic acid synthon ${ }^{21}$ failed. Eventually, we turned to the $\operatorname{Pd}(0)$-catalyzed coupling of a $H$-phosphite with a vinyl bromide in order to form the desired C-P linkage. Thus, coupling the protected inositol 9 with dibenzyl $N, N$-diisopropylphosphor-amidite gave the phosphoramidite intermediate 10, which was converted to $H$-phosphonate $\mathbf{1 1}$ in $76 \%$ isolated yield for two steps. 25 The 1-bromo-1-fluoroolefin 7 ( 1:1 E/Z) was 26 separately prepared via a $E_{2} Z$ Zn-promoted olefination reaction of $\mathrm{CBr}_{3} \mathrm{~F} / \mathrm{PPh}_{3}$ with glyceraldehyde 6 in excellent yield.

Few examples exist of $\mathrm{Pd}(0)$-catalyzed formation of P-CF bonds, and in our hands only traces of coupled compound $\mathbf{1 2}$ and with a majority of the P-O cleaved compound $\mathbf{9}$ were obtained under standard conditions using $\mathrm{Et}_{3} \mathrm{~N}$ or $\mathrm{K}_{2} \mathrm{CO}_{3}$ as base. It appeared that the rate of decomposition was faster than the rate of coupling for the more hindered $H$-phosphonate 11. To overcome this problem, we selected propylene oxide as a weak Lewis base and an effective scavenger of $\mathrm{HBr}^{27}$ Using this modification, treatment of the $H$-phosphonate 11 with $\mathrm{Pd}$ $(\mathrm{OAc})_{2} / \mathrm{dppf} /$ propylene oxide in THF at $70^{\circ} \mathrm{C}$ led to the formation of $\alpha$-fluorovinylphosphonate 12 in $62 \%$ yield. Acetal 12 was selectively deprotected by treatment with $60 \%$ aqueous trifluoroacetic acid in tetrahydrofuran at $0{ }^{\circ} \mathrm{C}$ to give diol 13. Next, acylation of $\mathbf{1 3}$ with either octanoic acid, palmitic acid, or oleic acid provided the fully-protected phosphonates 14a, $\mathbf{1 4 b}$ and $\mathbf{1 4 c}$ in $80 \%, 73 \%$ and $82 \%$ yields, respectively. Hydrogenolysis of $\mathbf{1 4 a}$ a $\mathrm{n}$ d $\mathbf{1 4 b}$ removed the benzyl groups, and then reaction with ethanethiol removed the MOM groups to give the $\alpha$-fluoromethylenephos-phonate analogues 1 and $2 .{ }^{28}$ The $\alpha$-fluorovinylphosphonates $\mathbf{3}, \mathbf{4}, \mathbf{5}^{28}$ were obtained by deprotection of benzyl and MOM groups simultaneously with TMSBr/TMSI (5:1).

Recently, the hydrolysis of the water-soluble dioctanoyl PtdIns $(4,5) \mathrm{P}_{2}$ was found to be important in the desensitization of TRPM4 channel (activated by cytoplasmic $\mathrm{Ca}^{2+}$ ). Exogenous PtdIns $(4,5) \mathrm{P}_{2}$ could restore the sensitivity of TRPM4 channels to $\mathrm{Ca}^{2+}$, demonstrating that PtdIns $(4,5) \mathrm{P}_{2}$ was a general regulator for the gating of TRPM4 ion channels. 15 The ability of the two dioctanoyl-PtdIns(4,5) $\mathrm{P}_{2}$ analogues 2 and 4 to restore TRPM4 currents following rundown is shown in Figure 1. Both analogues restored TRPM4 sensitivity following desensitization, but the $\alpha$-fluorovinylphosphonate $\mathbf{4}$ was more potent. Indeed, the unsaturated phosphonate 4 was even more effective than the hydrolyzable dioctanoyl-PtdIns $(4,5) \mathrm{P}_{2}$ at restoring TRPM4 sensitivity. This provides further evidence that the regulation of TRPM4 by dioctanoyl-PtdIns $(4,5) \mathrm{P}_{2}$ and the ability of dioctanoyl-PtdIns $(4,5) \mathrm{P}_{2}$ to restore TRPM4 currents following rundown is not due to effects of products of PLC hydrolysis. ${ }^{15}$

To determine sensitivity of TRPM4 currents to $\mathbf{2}$ and $\mathbf{4}$, we measured the effects of varying concentrations of both compounds on the recovery of TPRM4 currents in excised inside-out patches evoked in response to $100 \mu \mathrm{M} \mathrm{Ca}^{2+}$ (Figure 2). Maximal recovery of TRPM4 currents was observed upon reaching $10 \mu \mathrm{M}$ for both $\mathbf{2}$ and $\mathbf{4}$, and half-activation was observed at $\sim 2$ $\mu \mathrm{M}$ for both compounds, which is similar to the concentration of $\operatorname{PtdIns}(4,5) \mathrm{P}_{2}$ that promoted half-activation of TRPM4 $(6 \mu \mathrm{M}) .{ }^{15}$ The difference between the effectiveness of $\mathbf{2}$ and $\mathbf{4}$ in restoring TRPM4 currents (Figure 1) appears to result from differential abilities to promote activation of the TRPM4 channel. Taken together, these data suggest that the $\alpha$ fluorovinylphosphonate $\mathbf{4}$ is a biologically-active, long-lived mimic of $\operatorname{PtdIns}(4,5) \mathrm{P}_{2}$.

In conclusion, we developed an efficient synthesis of two non-hydrolyzable PtdIns $(4,5) \mathrm{P}_{2}$ analogues, and we showed that $\alpha$-fluorovinylphosphonate $\mathbf{4}$ optimally restored the sensitivity 
of TRPM4 currents. These results suggest that metabolically-stabilized analogues of PtdIns $(4,5) \mathrm{P}_{2}$ will have a wide variety of applications in separating the role of the phosphoinositide per se from activities that result when $\operatorname{Ins}(1,4,5) \mathrm{P}_{3}, \mathrm{DAG}, \mathrm{Ca}^{2+}$, or other downstream signals are generated from the hydrolysis of PtdIns $(4,5) \mathrm{P}_{2}$ by PLC.

\section{Supplementary Material}

Refer to Web version on PubMed Central for supplementary material.

\section{Acknowledgements}

We thank the NIH (Grant NS 29632 to GDP and DC 004564 to ERL) for financial support of this work.

\section{References}

1. McLaughlin S, Murray D. Nature 2005;438:605-611. [PubMed: 16319880]

2. Anderson RA, Boronenkov IV, Doughman SD, Kunz J, Loijens JC. J Biol Chem 1999;274:9907-9910. [PubMed: 10187762]

3. Doughman RL, Firestone AJ, Anderson RA. J Membr Biol 2003;194:77-89. [PubMed: 14502432]

4. McLaughlin S, Wang J, Gambhir A, Murray D. Annu Rev Biophys Biomol Struct 2002;31:151-175. [PubMed: 11988466]

5. Sciorra VA, Rudge SA, Wang J, McLaughlin S, Engebrecht J, Morris AJ. J Cell Biol 2002;159:1039_ 1049. [PubMed: 12486109]

6. Hilgemann DW, Feng S, Nasuhoglu C. Sci STKE 2001;2001:RE19. [PubMed: 11734659]

7. Suh BC, Hille B. Curr Opin Neurobiol 2005;15:370-378. [PubMed: 15922587]

8. Berridge MJ. Nature 1993;361:315-325. [PubMed: 8381210]

9. Berridge MJ. Annu Rev Biochem 1987;56:159-193. [PubMed: 3304132]

10. Cantley LC. Science 2002;296:1655-1657. [PubMed: 12040186]

11. Suh BC, Hille B. Neuron 2002;35:507-520. [PubMed: 12165472]

12. Zhang H, Craciun LC, Mirshahi T, Rohacs T, Lopes CM, Jin T, Logothetis DE. Neuron 2003;37:963975. [PubMed: 12670425]

13. Chuang HH, Prescott ED, Kong H, Shields S, Jordt SE, Basbaum AI, Chao MV, Julius D. Nature 2001;411:957-962. [PubMed: 11418861]

14. Prescott ED, Julius D. Science 2003;300:1284-1288. [PubMed: 12764195]

15. Zhang Z, Okawa H, Wang Y, Liman ER. J Biol Chem 2005;280:39185-39192. [PubMed: 16186107]

16. Liu D, Liman ER. Proc Natl Acad Sci USA 2003;100:15160-15165. [PubMed: 14657398]

17. Liu B, Zhang C, Qin F. J Neurosci 2005;25:4835-4843. [PubMed: 15888659]

18. Liu B, Qin F. J Neurosci 2005;25:1674-1681. [PubMed: 15716403]

19. Rohacs T, Lopes CM, Michailidis I, Logothetis DE. Nat Neurosci 2005;8:626-634. [PubMed: 15852009]

20. Berkowitz DB, Bose M. J Fluorine Chem 2001;112:13-33.

21. Xu Y, Prestwich GD. J Org Chem 2003;68:5320-5330. [PubMed: 12816494]

22. Prestwich GD, Xu Y, Qian L, Gajewiak J, Jiang G. Biochem Soc Trans 2005;33:1357-1361. [PubMed: 16246118]

23. Xu Y, Lee SA, Kutateladze TG, Sbrissa D, Shisheva A, Prestwich GD. J Am Chem Soc 2006;128:885897. [PubMed: 16417379]

24. Kubiak RJ, Bruzik KS. J Org Chem 2003;68:960-968. [PubMed: 12558421]

25. Chen J, Prestwich GD. J Org Chem 1998;63:430-431. [PubMed: 11672027]

26. Lei X, Dutheuil G, Pannecoucke X, Quirion JC. Org Lett 2004;6:2101-2104. [PubMed: 15200295]

27. Abbas S, Bertram RD, Hayes CJ. Org Lett 2001;3:3365-3367. [PubMed: 11594835] 
28. Note on stereochemistry. Both compounds 1 and 2 are inseparable mixtures of diastereomers at the C-F stereocenter, and the chiral phosphorus atom is racemic. Similarly, compounds 3, 4, 5 and $12-$ 14 are inseparable $\mathrm{E} / \mathrm{Z}$ mixtures. 
A
(4)

Ptdlns $(4,5) \mathrm{P}_{2}$

(2)

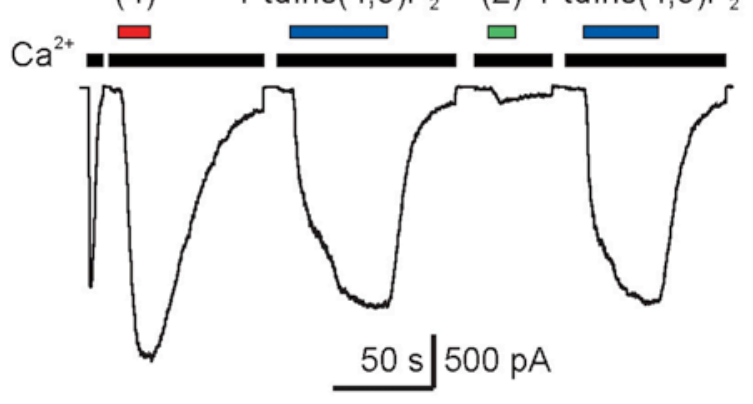

$\mathrm{B}$

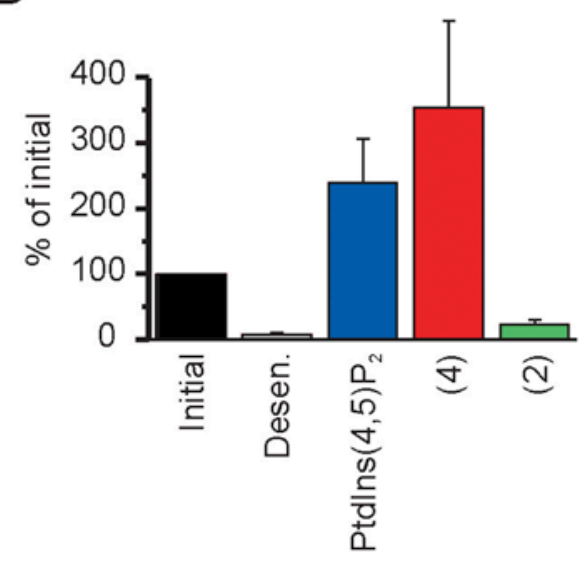

Figure 1.

PtdIns $(4,5) \mathrm{P}_{2}$ and analogues $\mathbf{2}$ and $\mathbf{4}$ restore TRPM4 currents following desensitization. $\boldsymbol{A}$. An excised inside-out patch from Chok1 cell expressing mouse TRPM4 (mTRPM4) shows activation and fast rundown of an inward current in the presence of $100 \mu \mathrm{M} \mathrm{Ca}^{2+}$ and recovery by dioctanoyl-PtdIns $(4,5) \mathrm{P}_{2}$ and analogues 2 and $\mathbf{4}\left(\mathrm{V}_{\mathrm{m}}=80 \mathrm{mV}\right)$. $\boldsymbol{B}$. Initial magnitudes of the mTRPM4 currents, currents after rundown, and currents after recovery in response to $10 \mu \mathrm{M}$ each of PtdIns $(4,5) \mathrm{P}_{2}, \mathbf{2}$, and 4 (averages, $\mathrm{n}=8$ ). 


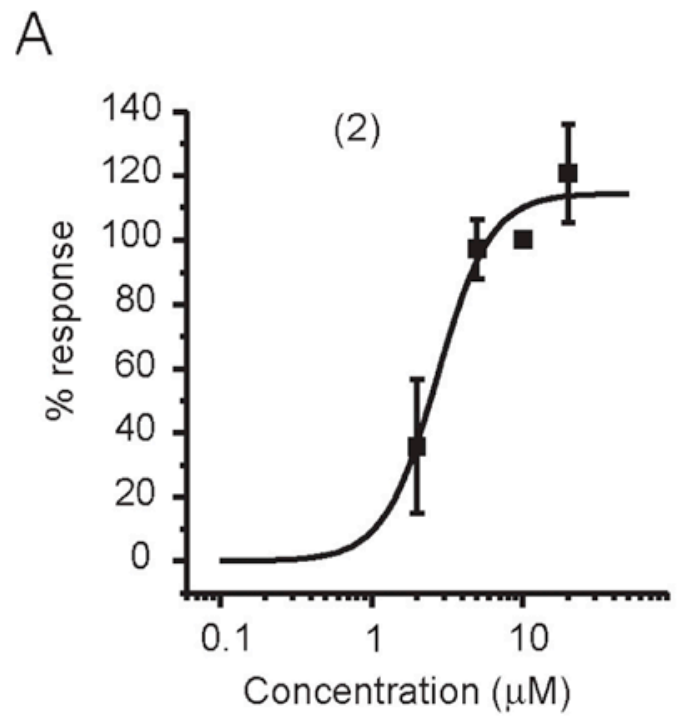

B

Figure 2.

Dose-response for recovery of TRPM4 currents by $\mathbf{2}$ and $\mathbf{4}$. After TRPM4 desensitization, recovery was assessed. Data were normalized to the response to $10 \mu \mathrm{M}$ of each analogue in the same patch. $\boldsymbol{A}$. Averaged data $(\mathrm{n}=5)$ for recovery of TRPM4 currents by $\mathbf{2}\left(\mathrm{EC}_{50}=2.7 \pm\right.$ $0.6 \mu \mathrm{M}$ and $\left.n_{\mathrm{H}}=2.5 \pm 1.2\right)$. B. Averaged data $(\mathrm{n}=6)$ for $4\left(\mathrm{EC}_{50}=1.8 \pm 0.1 \mu \mathrm{M}\right.$ and $n_{\mathrm{H}}=3.2$ \pm 0.5 ). 


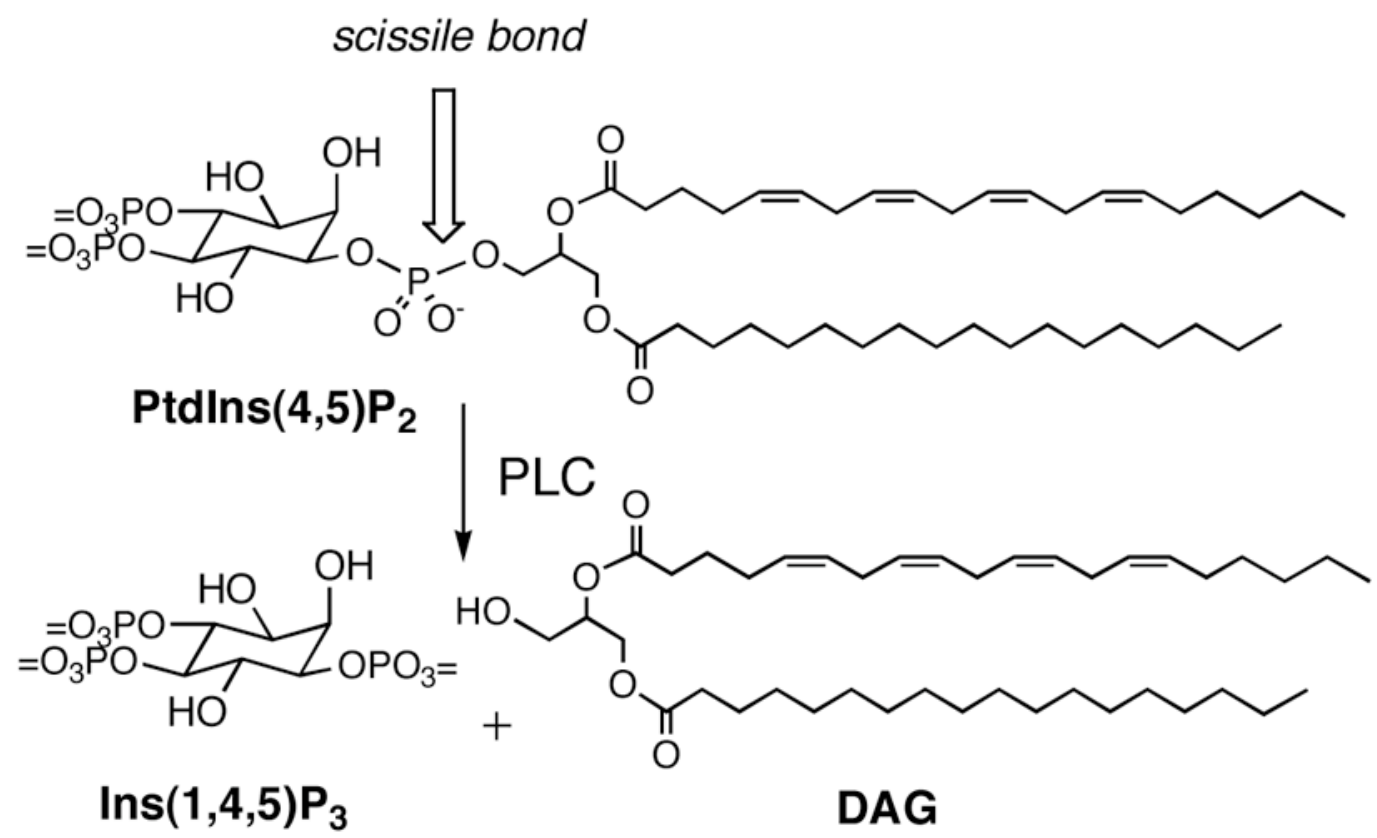

Scheme 1.

Phospholipase C catalyzes hydrolysis of PtdIns(4,5) $\mathrm{P}_{2}$ to two second messengers, Ins $(1,4,5)$ $\mathrm{P}_{3}$ and diacylglycerol 

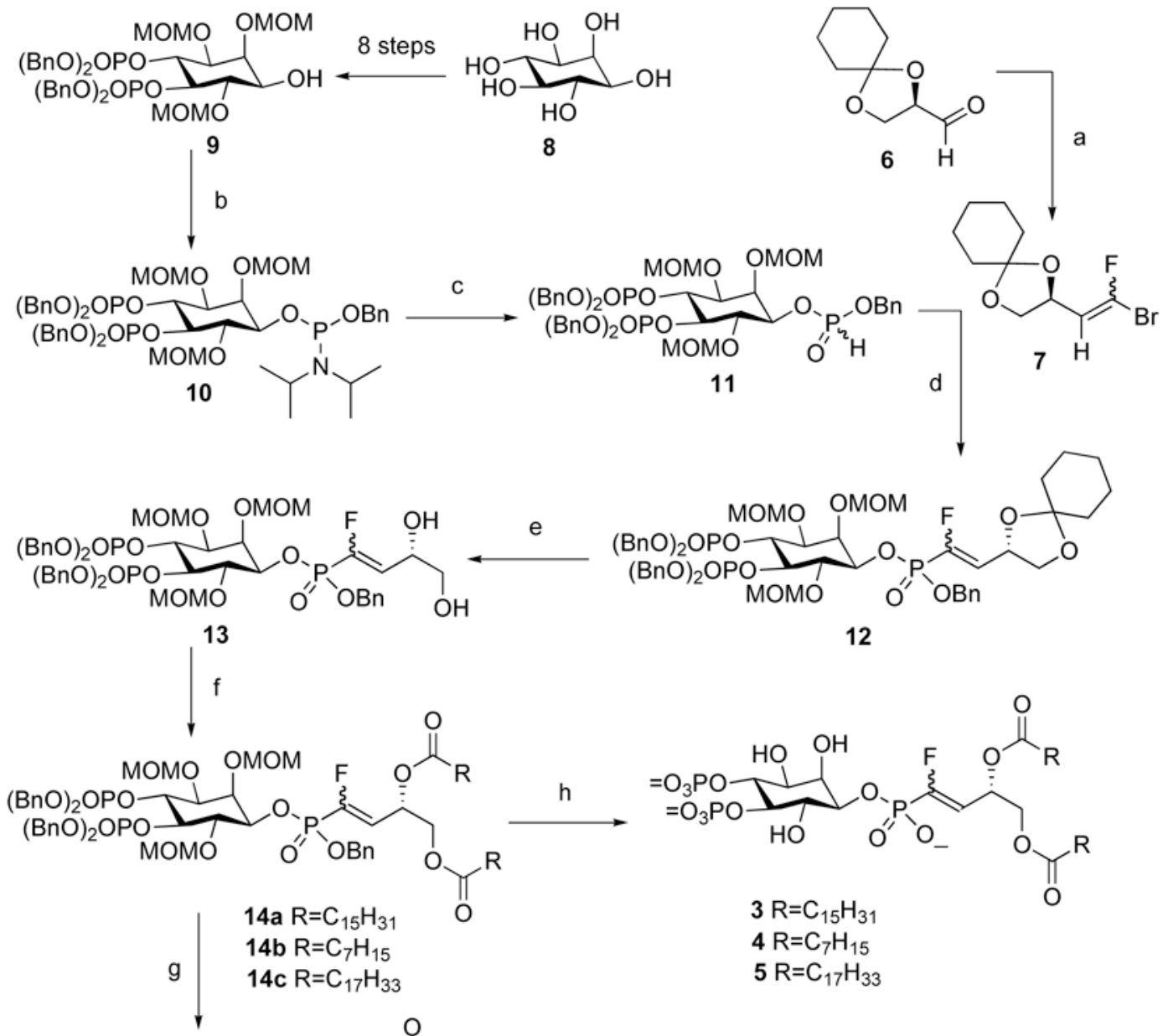

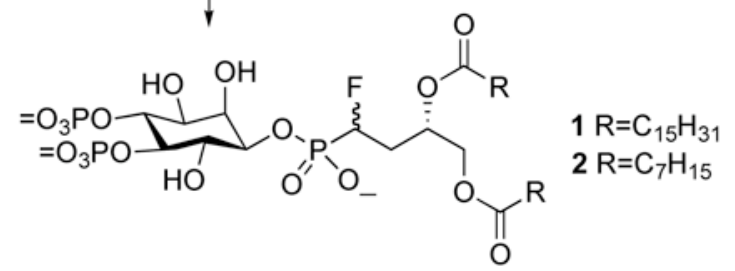

Scheme 2.

Synthesis of phosphonates $\mathbf{1}-\mathbf{5}^{\mathrm{a}}$

a (a) $\mathrm{CFBr}_{3}, \mathrm{PPh}_{3}, \mathrm{Et}_{2} \mathrm{Zn}$, THF, 76\%; (b) (BnO) ${ }_{2} \mathrm{P}\left(\mathrm{NPr}_{2}-i\right)_{2}, N, N$-disopropylethylammonium - $1 \mathrm{H}$-tetrazole, $\mathrm{CH}_{2} \mathrm{Cl}_{2}$, rt; (c) $\mathrm{H}_{2} \mathrm{O}, 1 \mathrm{H}$-tetrazole, $\mathrm{rt}, 1 \mathrm{~h}, \mathrm{CH}_{2} \mathrm{Cl}_{2}, 76 \%$ for two steps; (d) $\mathrm{Pd}$ (OAc) $)_{2}$, dppf, propylene oxide, THF, $70{ }^{\circ} \mathrm{C}, 62 \%$; (e) $60 \%$ aqueous TFA, THF, $0^{\circ} \mathrm{C}, 1 \mathrm{~h}, 86 \%$; (f) EDCI, DMAP, fatty acid, $\mathrm{CH}_{2} \mathrm{Cl}_{2}$, rt; (g) $\mathrm{H}_{2}, \mathrm{Pd} / \mathrm{C}, \mathrm{MeOH}, 6 \mathrm{~h}$; EtSH; (h) TMBr/TMSI (5:1), rt, $1.5 \mathrm{~h} ; \mathrm{MeOH}, 1 \mathrm{~h}$. 